\title{
DE INDIANEN IN CANADA
}

DOOR

JHR. L. C. VAN PANHUYS

Op den laatsten Augustus 1933 kon de heer H. W. McGill, „Deputy Superintendent General” van Indiaansche zaken, aan zijn chef te Ottawa rapporteeren, dat de Indianen zich redelijk wel in betrekking tot de economische en gezondheidsomstandigheden hadden weten te handhaven, indien men rekening hield met den ongunstigen toestand, die in Canada in het algemeen heerschte. Indianen in dienst als fabrieksarbeider hadden echter als een bijzonder nadeel ondervonden, dat blanke concurrent-arbeiders eerder dan zij werk hadden kunnen krijgen.

Daarentegen verkeerden Indiaansche landbouwers, in het bijzonder in de Prairie-provincies, in economischen zin in een veel betere positie dan hun blanke buren; zij waren zeer voorspoedig, en de heer McGill schrijft dezen bijzonder gunstigen toestand toe aan de voortdurende intensieve hulp en het onderwijs, dat de regeering gedurende de laatste halve eeuw aan de Indianen heeft verschaft. $Z$ ij hebben ook vrijdom van belastingen genoten en waren aldus tegen achteruitgang beschermd. Als men er aan denkt, dat deze Indianen, nadat de buffel in 1878 was uitgestorven ${ }^{1}$ ), in nood verkeerden in die mate, dat zij slechts door voedselverstrekking van regeeringswege in het leven konden worden gehouden, dan staat men nu voor het merkwaardige feit, dat een politiek van vooruitgang hen in slechts twee generaties zoover vooruit heeft gebracht, dat zij nu in hun eigen bestaan kunnen voorzien.

De Indianen, die in meer afgelegen districten van de jacht leven, hebben het goed bij hun eigen eenvoudigen en gezonden levensstandaard; zij, die zich ophouden in de gebieden tusschen beschaafde en woeste streken, staan echter voor de moeilijkheid, dat daar de jachtdieren, die bont leveren, schaars worden en

1) Er staat letterlijk: „After the failure of the buffalo". 
blanke jagers in steeds grooter getal op hun jachtvelden komen. De Indiaansche visschers aan de westkust van Britsch Columbia hebben sterk te lijden door den achteruitgang van de visscherijbedrijven.

De getalsterkte van de Indiaansche bevolking bedraagt ongeveer 108.000 en hun aantal is in de laatste jaren niet achteruit gegaan.

Uit het verslag blijkt verder, dat het Parlement in de zitting van het voorjaar van 1933 verschillende amendementen aannam betreffende de „Indian Act”. Het meest trok de vraag van de vrijmaking (enfranchisement) de aandacht, die echter geen verband houdt met het recht van den Indiaan om te stemmen bij verkiezingen in het Dominion. Er zijn vele niet vrijgemaakte Indianen, bijvoorbeeld die als soldaat zijn teruggekeerd, die toch stemrecht hebben. Hoewel zij stemrecht hebben, blijven zij „wards" van de Kroon, en onderworpen aan de bepalingen van de Indian Act. Vrijgemaakte Indianen ressorteeren echter niet langer onder de bepalingen van de genoemde akte of wet, en zijn vrij van de voogdij van de Kroon. Er moest worden voorzien in den ontstanen mistoestand, dat Indianen, die volkomen in staat waren voor zichzelf te zorgen, niettemin om redenen van persoonlijken aard van de bescherming van de Indian Act bleven gebruik maken, en dat terwijl zij door opvoeding en bekwaamheid volkomen in staat waren de volle verantwoordelijkheid van het vrije burgerschap te dragen. In vele gevallen van dien aard waren Indianen van de bedoelde categorie, hoewel door vaderlijke afstamming den staat van „Indiaan” bezittende, door huwelijken over vele geslachten geheel als blanken grootgebracht en lichamelijk niet meer als Indiaan te herkennen. Sommigen van deze „Indianen volgens de Wet" waren op reservaties (op voor Indianen beschikbaar gesteld of bewaard, dus voor hen gereserveerd, land) aanwezig, die rood haar en blauwe oogen hadden en, zegt het verslag, zeer schoone gelaatstrekken toonden.

Bij amendement werd o.a. aan Indianen verboden om zonder schriftelijke vergunning van den Agent voor Indiaansche zaken aan vreemden vee en voortbrengselen van den akker te verkoopen. Aan de Indiaansche raden, door verkiezing ontstane lichamen, die eenigszins aan gemeenteraden doen denken, werd toegestaan toezicht te houden op kooplieden, die de reservatie betraden. Alle verordeningen, die de „Indian Councils” maken, behoeven de goedkeuring van den Gouverneur in rade; zij betref- 
fen onderwerpen als de zorg voor de openbare gezondheid; de inachtneming van orde en waardigheid in den algemeenen raad; het voorkomen van wangedrag en van het geven van overlast; het voorkomen van veediefstal, de bescherming van vee; den aanleg of den bouw en het onderhoud van kanalen, wegen en bruggen, enz.; den bouw en het herstel van scholen en raadhuizen; het aanhouden van bevolkingsregisters; het wieden van onkruid; het toezicht op sportwedstrijden, enz.

Wat de gezondheidstoestand aangaat wordt vermeld, dat de Indianen van Canada gedurende verscheidene jaren niet te lijden hadden van belangrijke infectie-ziekten. Vaccinatie was in de laatste vijf jaren zoo grondig toegepast, dat de pokken, voor welke ziekte de Indianen zoo vatbaar zijn, vermoedelijk niet meer in epidemischen vorm zullen optreden. Influenza trad niet op den voorgrond en was niet van een kwaadaardig karakter. Er waren in het jaar, eindigende op 31 Maart 1933, slechts zeer enkele gevallen van diphterie en van roode hond. Mazelen en kinkhoest kwamen echter veelvuldig voor en veroorzaakten veel sterfgevallen onder jonge kinderen. De Indiaansche moeders staan achter bij de blanke moeders op het stuk van bekwaamheid om een ziek kind te verplegen. Voor sommige, aan rivieren met besmet water gelegen gemeenten wordt jaarlijksche inspuiting met anti-typhoide middelen aanbevolen. De Indianen helpen zelf mede om de (niet talrijke) gevallen van syphilis te bestrijden. Organische hartziekte, suikerziekte, chronische lever-aandoening en kanker komen slechts voor in de Indiaansche gemeenten, die zich sterk met blanken hebben vermengd. Het zou voor de wetenschap van veel belang zijn, indien b.v. kon worden ontdekt, waarom Indianen vrij blijven van kanker. De sterften aan tuberculosis zijn bij de Indianen veel en veel talrijker dan bij de blanke bevolking; de bestrijding ontmoet veel bezwaren. Er zijn 7 à 8000 gevallen van trachoom. Van een stam, ,band”, van 700 Indianen waren 11 blind en 200 met trachoom besmet. Er zal voor de bestrijding vooral getracht moeten worden om maatregelen te nemen op de Indiaansche Residential Schools. Het departement voor Indiaansche zaken beschikt over een medischen staf.

Fr waren in 't geheel 340 Indiaansche scholen, waarop 17.425 leerlingen waren ingeschreven. De Indiaansche ouders zijn er vooral op gesteld hun kinderen naar de Residential Schools te zenden, waarvan het aantal 80 bedraagt. Daarvan zijn 44 Roomsch 
katholiek; de 36 overigen zijn scholen van de Church of England, van de United Church en van de Presbyterian Church. Er zijn bovendien nog 9 scholen van het Departement, met een gemengde blanke en Indiaansche schoolbevolking. Op de residential scholen wordt o.a. land- en tuinbouw, veeteelt en ambachtsonderwijs gegeven. Tweehonderd en dertig Indiaansche studenten, die in de bovenverstrekte cijfers niet begrepen zijn, volgen het onderwijs op andere scholen, op hoogescholen en op "Colleges”. Aan het onderwijs voor Indianen werd voor het jaar, eindigende op 31 Maart 1933, een bedrag besteed van 1.712.223 dollars.

Wat de door Indianen beoefende landbouw betreft, deze neemt van jaar tot jaar toe; de oogsten steken gunstig af bij die, welke door blanke landbouwers worden verkregen. Tarwe, haver, wortelen, groenten, veevoeder en hooi zijn belangrijke voortbrengselen. In het bijzonder draagt de teelt van wortelen en van groenten er toe bij om den Indiaan gezonder en rijker voedsel te verschaffen. Er wordt veel aan veeteelt gedaan. Maar er dient vanwege het departement ook veel toezicht te worden gehouden; de verkregen goede uitkomsten zijn vooral te danken aan de voortdurende waakzaamheid van een korps bekwame landbouwleeraren.

Door Indianen werd ongeveer vijf en twintig millioen kubieke voet hout geveld voor verkoop en negen millioen voor woningbouw, omheiningen en brandhout. $\mathrm{Zij}$ betaalden aan vergunningsrechten om hout te vellen een bedrag van meer dan 46.000 dollars. Er kwamen op de Indiaansche reservaties nog 25 boschbranden voor, vooral in de provincie Ontario; sommige boschbranden waren moedwillig aangestoken, doch het bewijs viel moeilijk te leveren. Er moest meer dan tienduizend dollars worden uitgegeven aan loon voor Indiaansche brandweerlieden.

Het departement telt 116 agentschappen voor het beheer van de Indiaansche reservaties, die over geheel Canada liggen verspreid. De waarde van het land van de reservaties wordt door het departement geschat op bijna 54 millioen dollars; de totale waarde van werkelijk en persoonlijk eigendom van de Indianen $\cdot o p$ ongeveer 72 millioen dollars.

Van de 108000 Indianen worden ongeveer 41000 opgegeven als tot enkele Protestantsche sekten behoorende,en meer dan 52.800 als Roomsch-Katholiek, bijna 5000 als hebbende ,aboriginal beliefs" terwijl van 7587 Indianen de godsdienst onbekend is. Het talrijkst is de Indianenbevolking in Ontario (27.420) en in Britsch Colum- 
bia (25.107). De groote meerderheid in Ontario zijn Ojibwas, van de Algonquinsche familie, maar er zijn ook Mohawks van de Irokeezen familie. In deze provincie zijn de Indianen vooral landbouwers, onder wie zich de teruggekeerde soldaten bijzonder onderscheiden. In den zomer treden velen op als gids en als kanovaarder. De groote meerderheid van de Indiaansche boeren leeft in goede boerenwoningen, die gunstig bij die van de blanke landbouwers afsteken. Het maken van sneeuwschoenen, kano's en mocassins is het werk van de oudere mannen; de vrouwen vervaardigen vlechtwerk, en het verzamelen van boschbessen verschaft hen in sommige districten een goed inkomen. De Indianen in Britsch Columbia behooren tot de Salish-stammen; ook vindt men er de Kwakiutl, de Haidas en de Tlingits en verder Indianen van het Athapasca-ras. Er zijn 2500 Indiaansche nomaden, die men naar taal of stam niet nauwkeurig kan indeelen. Hier zijn de Indianen vooral visschers, die vaak zelf een motorboot met netten en toebehooren in eigendom hebben Mannen en vrouwen arbeiden er in de conserveerfabrieken (canneries). Een deel heeft zich op den landbouw toegelegd; in de afgelegen districten leven de Indianen van jagen en van strikken zetten. 